\title{
CEO Gender And Earnings Management
}

\author{
Kyunga Na, Keimyung University, South Korea \\ Jooyeon Hong, Sungkyunkwan University, South Korea
}

\begin{abstract}
Using the female CEO and male CEO groups over a 14-year (1992-2013) period, we find that the male CEOs use aggressive discretionary accruals and real activities operations in order to report small positive earnings or small earnings increases whereas the earnings management using real activities operation of suspect firms disappear in the female CEO group.
\end{abstract}

Keywords: CEO Gender; Earnings Management; Accruals Earnings Management; Real Activities Management

\section{INTRODUCTION}

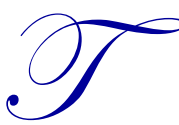

he gender effect on human behavior has long been a controversial topic across academic fields. In the recent years, the gender issue has drawn attention in business and finance areas. Many European countries have passed laws that require a minimum number of female directors on the board. For example, Norway has required that $40 \%$ of the board members of a company be female since 2008 while Spain has mandated the same condition since 2015. Following Norway and Spain, other European countries have considered enacting similar laws. This legal movement for gender diversity on the board of directors seems to stem from the notion that female directors are less likely to take high risks and more likely to be ethical than male directors, suggesting that hiring female executive members could increase the transparency of firms (Betz et al. 1989; Niessen and Ruenzi 2006).

One method of gauging the transparency of firms is estimating the earnings management of the firms. Since the CEO has the power to make decisions for a firm, the gender of CEO may affect the earnings management of the firm. Specifically, a CEO's gender may influence the earnings management of a firm when the CEO of the firm has a strong incentive to inflate earnings in order to achieve profit or earnings increases. To address this issue comprehensively, we first define suspect firms as those which achieve small earnings or small earnings increases, where earnings management are most likely to occur according to previous studies (Roychowdhury 2006; Gunny 2010; Zang 2011). Then, we divide the sample into firms with male CEOs and those with female CEOs, and examine earnings management of suspect firms across the two subsamples. To estimate a firm's earnings management activities, we use both accrual management, proxied by the performance-matched discretionary accruals estimated from the modified Jones model (Dechow et al.1995; Kothari et al. 2005), and real management, proxied by abnormal cash flow from operations, abnormal production costs and abnormal discretionary expenses (Roychowdhury 2006). Also, this study investigates using both the ordinary least square (hereinafter OLS) method and Heckman's (1979) two-stage procedure to control for sample selection bias. The major findings of this paper are as follows. First, we observe that suspect firms manage earning significantly by accruals and real activities to avoid losses or earnings decreases. The same pattern of earnings management also appears when the CEO gender of suspect firms is male, but disappears when the CEO gender is female. The results suggest that a male CEO manages discretionary accruals and real activities to avoid losses or earnings decreases while female CEO does not. All results are qualitatively the same when we use the OLS or Heckman's (1979) method.

The prior accounting research also investigates the effects of gender on the quality of accounting information, such as accruals or earnings quality. Several studies document that firms with gender diversity in the board of directors or a female CFO have better accrual quality (Krishnan and Parsons 2008; Barua et al. 2010; Peni and Vähämaa 2010). On the other hand, El-Mahdy (2015) finds that female CFOs are less likely to manage earning through real activity operations within the generally accepted accounting standards compared to male CFOs. This study has several major 
differences from the aforementioned papers. First, the focus of other studies is the CFO gender, whereas we examine the effect of CEO gender since the CEO is the main decision maker of a firm. CEOs or CFOs have different roles in managerial decisions. The CEO has the power to make decisions for a firm, while the CFO is mainly responsible for financial reporting. Therefore, gender of CEO may affect the earnings management of a firm differently from that of CFO. Second, the previous studies look at the average level of abnormal accruals or abnormal real activities across the CFO gender. In contrast, this study focuses on the earnings management of suspect firms in which earnings management is most likely to occur and shows whether the CEO gender affects the earnings management of suspect firms. Lastly, we use a research model designed to control for sample selection bias from gender.

This study contributes to the current accounting by providing empirical evidence that the suspect firms are likely to manipulate earnings management if they are operated by male CEOs whereas suspect firms with female CEOs do not engage in earnings management. These results can shed a light on the notion that a female CEO is likely to be more conservative and make less risky decisions in terms of earnings management.

\section{LITERATURE REVIEW AND HYPOTHESIS DEVELOPMENT}

Gender has been regarded, across academic disciplines, as an influence on behaviour. Especially, many researchers in finance have called attention to the relations between gender and firm performance or firm characteristics. Among them, gender and the attitude to risk is a commonly examined research area. Previous studies find that female managers tend to avoid risk. For instance, Khan and Vieito (2013) document that female CEOs are positively associated with firm performance, and negatively associated with risk expressed as the standard deviation of return. This result suggests that female CEOs are more risk-averse than male CEOs, which is consistent with the results of Niessen and Ruenzi (2006) and Liu et al. (2014). Niessen and Ruenzi (2006) investigate the difference in investment decisions between male and female fund managers and find that female fund managers prefer less risky investments. Liu et al. (2014) show that female CEOs and three or more female board members are positively associated with their firm's performance. Sun and Liu (2014) also report that having female members in the audit committee is likely to increase firm performance and reduce risk, further suggesting that female managers are less likely to take risk.

\section{Previous Literature Also Focuses on Other Behavioral Differences Across the Genders}

Vinkenberg et al. (2011) argue that men are more likely to prioritize promotion than women do, implying that men have stronger incentive to manage earnings. Through a survey of 213 business school students, Betz et al. (1989) find that males are more susceptible to engage in unethical actions: they reveal that $50 \%$ of male respondents are willing to buy stocks using insider information, compared to $31 \%$ of female respondents. In contrast, Adams and Funk (2012) survey the effect of gender on the behaviour of the board of directors, and report that female directors are more merciful and less power-oriented, but also less tradition and security-oriented and more risk-loving than male directors. Except for one study, the overall results imply that female managers would be more cautious and have less incentive to engage in unethical behaviour than male managers.

Another stream of studies investigates the association between gender and stock prices to provide insight into the market reaction toward the gender of executives within a firm. Lee and James (2007) reveal that investors exhibit a negative abnormal return with the announcement of a female CEO appointment. However, the reaction is less harsh if the female CEO is promoted from inside the firm than from outside the firm. This finding suggests that investors hold negative views towards female CEOs, which may pressure female CEOs to make conservative decisions to maintain their positions. On the other hand, Huang and Kisgen (2013) reveal that male executives issue bonds and make acquisitions more frequently than female executives. They also find that the stock price is more negative to the announcements of acquisitions by male executives than to those by female executives.

In the recent years, several studies in accounting have explored the association between gender and accounting information. Krishnan and Parsons (2008) document that firms with greater gender diversity in their management have higher earnings quality in terms of conservatism, normal conditions, persistence, and loss avoidance tendency. Shawver et al. (2006) also reveal that female accountants have participated in less earnings management than the male counterparts. Barua et al. (2010) and Peni and Vähämaa (2010) focus on accrual quality and CFO gender. Barua et al. (2010) claim that female CFOs have high accrual quality expressed by lower discretionary accruals and lower accruals 
volatility. Peni and Vähämaa (2010) suggest that female CFOs are more associated with income-decreasing discretionary accruals. They interpret this as meaning that female CFOs tend to prefer conservative accounting choices. El-Mahdy (2015) claims that female CFOs engage in inflating earnings through real activities to show their abilities to the CEO of the firm.

Earnings management to achieve target earnings has been a frequently discussed area in accounting research. Burgstahler and Dichev (1997) find that the frequency of small positive earnings or small earnings increases is unusually higher than that of small negative earnings or small earnings decreases, suggesting that firms tend to inflate earnings to avoid small losses or small earnings decreases. In the same line of research, Degeorge et al. (1999) provide evidence that firm managers are likely to manage earnings to meet three earnings thresholds: zero earnings, last period's earnings, and analyst forecast consensus.

To measure a firm's earnings management, two earnings management methods are discussed in the prior accounting research: accrual management and real activity management. Accrual management refers to a firm's opportunistic behavior to achieve target earnings through accruals, which has long been used in the accounting literature. Since accrual management alters reported earnings through the accounting books, it does not change the cash flows of a firm. Also, accruals are usually reversed in the following period.

During the recent years, real activity management has attracted the interest of researchers. Real activity management is a technique to manipulate earnings through real action, which can harm firm value in the long run by changing a firm's cash flow. According to a survey by Graham, Havery and Rajgopal (2005), most CFOs prefer taking real action, such as cutting discretionary expenses, to meet benchmark earnings. On the other hand, Roychowdhury (2006) provides empirical evidence that firms achieving just above zero earnings are more likely to manage earnings through real activity to avoid losses. Specifically, Roychowdhury (2006) estimates real earnings management using three real activities: reduction in discretionary expenses, over-production, or sales manipulation. This evidence is further supported by Gunny (2010) who finds that firms use real activity management to meet either zero earnings or last year's earnings.

Finally, Zang (2011) examines the trade-offs between the two earnings management methods. Since earnings management is more likely to be used for meeting or beating important earnings benchmarks, Zang (2011) uses the following sample firms in her research: suspect firms meeting or beating zero earnings, the previous year's earnings, analyst forecast earnings, or management forecast earnings. Zang (2011) documents that accrual management and real activity management are used as substitutes, based on the relative cost of each method. He also reveals that decision on real earnings management precedes that of accrual management.

From the previous literature, we expect that earnings management to avoid losses or earnings decreases is likely to occur when the CEO is male, and is not likely when the CEO is female. In summary, a male CEO would be (1) willing to make the opportunistic, but risky and possibly unethical decision of managing earnings to maintain his short-run position; and (2) confident that he can make up for the effects of such management, whereas a female CEO would be reluctant to make such decisions. Thus, we construct the following hypotheses.

H1: Male CEOs are more likely to inflate earnings to avoid losses or earnings decreases.

H2: Female CEOs are not likely to manage earnings to avoid losses or earnings decreases.

\section{DATA AND SAMPLE}

The CEO-related data, such as gender, age, and compensation, are collected from COMPUSTAT Annual Compensation database between 1992 and 2013. The CEO for each company in each year is identified as a value of "CEO" in the annual CEO flag (CEOANN) variable, which indicates that this executive served as a CEO for all or most of the corresponding fiscal year. These data are merged with the financial data in the non-financial and nonregulated industries selected from COMPUSTAT Fundamental Annual database between 1990 and 2013 to form an 
initial sample of 25,599 firm-year observations between 1992 and 2013. ${ }^{1}$ The sample period begins in 1990 because one- to two-year lag data are required to calculate model variables in the regressions. ${ }^{2}$ Among them, we eliminate 7,451 observations that do not have the data to calculate the necessary variables. Then, we further delete 3,763 observations that do not satisfy the requirement of having at least 15 observations in each two-digit SIC industry-year group to estimate normal accruals, CFO, production costs, and discretionary expenses; thus arriving at the final sample of 14,385 observations. All continuous independent variables are winsorized at the top and bottom 1 percent of their respective distributions.

Table 1. Sample

Sample Selection Process

\begin{tabular}{l|c}
\hline \multicolumn{1}{c}{ Filtering process } & Number of observations \\
\hline CEO related data from COMPUSTAT Annual Compensation Database $(1992-2013)$ & 34,907 \\
\hline Financial data from COMPUSTAT Fundamental Annual Database $(1990-2013)^{\mathrm{a}}$ & 171,787 \\
\hline Merged two data (1992-2013) & 25,599 \\
\hline Less: Missing data in the necessary variables & $(7,451)$ \\
\hline Less: Industry-year groups with less than 15 observations & $(3,763)$ \\
\hline The final sample (1992-2013) & 14,385 \\
\hline Suspect firm sample (1992-2013) & 1,123 \\
\hline
\end{tabular}

The previous studies (Roychowdhury 2006, Durtschi and Easton 2005, Burgstahler and Dichev 1997) document firms are more likely to manipulate earnings to avoid losses or earnings decreases. To increase the possibility of detecting the firms' earnings management, we define suspect firm-years as observations whose net income or change in net income scaled by opening total assets falls into the range between 0 and 0.005 . From the final sample, 1,123 of observations are identified as suspect firm-years. Table 1 summarizes the above sample filter rules.

\section{RESEARCH DESIGN}

To test whether there is a CEO gender effect, we consider two sets of research analysis. First, we partition the sample into two subsamples based on the gender of a firm's CEO, male CEO sample and female CEO sample. Then, we construct the following ordinary-least-square (OLS hereinafter) regression, following Roychowdhury (2006), and run it on each subsample, separately. ${ }^{3}$

$$
\begin{aligned}
& \text { EM }_{i t}=\beta_{0}+\beta_{1} \text { Size }_{i t-1}+\beta_{2} \text { MTB }_{i t-1}+\beta_{3} \text { Leverage }_{i t-1}+\beta_{4} N I_{i t} \\
& +\beta_{5} \text { Suspect }_{i t}+\gamma_{j} \bullet \text { IndustryDummy }+\gamma_{t} \bullet \text { YearDummy }+\varepsilon_{i t}
\end{aligned}
$$

\section{Dependent Variable}

The dependent variable in Equation (1), EM, represents the extent of earnings management. As a proxy for a firm's earnings management, we consider both the accrual management (AM) and real activity management (RM) measures widely used in the previous accounting studies. Specifically, the performance-matched discretionary accruals (PMDA) are used for estimating a firm's accrual management whereas real activity management is given by abnormal cash flow from operations $\left(A b_{-} C F O\right)$, abnormal production costs (Ab_Prod), and abnormal discretionary expenses $\left(A b_{-}\right.$Disexp $)$. The detailed estimation procedure of each measure is as follows. Subscripts $i, t$, and $j$ represent sample firm $i$ in year $t$ and industry $j$.

AM measure $(P M D A)$ : To mitigate potential measurement errors, we use performance-matched discretionary accruals as a proxy for earnings management through accruals (Kothari, Leone and Wasley 2005). First, we estimate discretionary accruals based on the original Jones model (Jones 1991, Kothari et al. 2005), described below. ${ }^{4}$

\footnotetext{
${ }^{1}$ The Financial and Regulated industries include SIC 6000-6999 and SIC 4400-5000, respectively.

${ }^{2}$ The starting point of 1990 in financial data allows us to calculate total accruals using the income statement approach, which is considered conceptually superior to the balance sheet approach (Hribar and Collins 2002).

${ }^{3}$ Following Petersen (2009), $t$-values are calculated using robust standard errors to correct for potential problems associated with heteroskedasticity and firm clustering.

${ }^{4}$ All variables in Equation (3) are winsorized at the top and bottom 1 percent of their respective distributions.
} 


$$
\frac{T A C_{i t}}{T A_{i t-1}}=\alpha_{1} \frac{1}{T A_{i t-1}}+\alpha_{2} \frac{\Delta S_{i t}}{T A_{i t-1}}+\alpha_{3} \frac{P P E_{i t}}{T A_{i t-1}}+\varepsilon_{i . t}
$$

where TAC denotes total accruals, defined as income before extraordinary items minus cash flows from operating activities; $T A$ denotes total assets; $\triangle S$ denotes changes in sales; $P P E$ denotes gross property, plant and equipment. Subscripts $i, t$, and $j$ represent sample firm $i$ in year $t$ and industry $j$. The residuals from Equation (2) estimated by twodigit SIC industry and year represent discretionary accruals for sample firm $i(D A C C)$.

Next, the performance-matched discretionary accrual for firm $i$ is calculated as firm $i$ 's discretionary accruals minus the matched firm's discretionary accruals that has the closest return on assets (ROA) ${ }^{5}$ within the same industry-year group. In the event of ties on ROA, we select the firm with the closest firm size expressed as a natural logarithm of assets.

RM measure: As a proxy for a firm's real activity management, we estimate abnormal cash flow from operations $\left(A b \_C F O\right)$, abnormal production costs $\left(A b_{-}\right.$Prod $)$, and abnormal discretionary expenses (Ab_Disexp), using the following three equations from Roychowdhury (2006). ${ }^{6}$

$$
\begin{aligned}
& \frac{C F O_{i t}}{T A_{i t-1}}=\alpha_{0}+\alpha_{1}\left(\frac{1}{T A_{i t-1}}\right)+\alpha_{2}\left(\frac{S_{i t}}{T A_{i t-1}}\right)+\alpha_{3}\left(\frac{\Delta S_{i t}}{T A_{i t-1}}\right)+\varepsilon_{i t} \\
& \frac{\operatorname{Prod}_{i t}}{T A_{i t-1}}=\alpha_{0}+\alpha_{1}\left(\frac{1}{T A_{i t-1}}\right)+\alpha_{2}\left(\frac{S_{i t}}{T A_{i t-1}}\right)+\alpha_{3}\left(\frac{\Delta S_{i t}}{T A_{i t-1}}\right)+\alpha_{4}\left(\frac{\Delta S_{i t-1}}{T A_{i t-1}}\right)+\varepsilon_{i t} \\
& \frac{\operatorname{Disexp}_{i t}}{T A_{i t-1}}=\alpha_{0}+\alpha_{1} \frac{1}{T A_{i t-1}}+\alpha_{2} \frac{S_{i t-1}}{T A_{i t-1}}+\varepsilon_{i t}
\end{aligned}
$$

where $C F O$ denotes cash flow from operations; $T A$ denotes total assets; $S$ denotes sales; $\triangle S$ denotes changes in sales; Prod denotes production costs, defined as the sum of cost of goods sold and change in inventory; Disexp denotes discretionary expenses. The residuals from Equations (3)-(5), estimated by each industry and year, represent abnormal cash flow from operations $\left(A b_{-} C F O\right)$, abnormal production costs $\left(A b \_P r o d\right)$, and abnormal discretionary expenses ( $A b_{-}$Disexp) for sample firm $i$, respectively.

\section{Test Variables}

The test variable in Equation (1) is the suspect firm years (Suspect) as an indicator variable, set equal to one if $N I$ or change in $N I(\Delta N I)$ is equal to or greater than 0 but less than 0.005 and zero otherwise.

\section{Control Variables}

Equation (1) includes control variables from Roychowdhury (2006). ${ }^{7}$ They are firm size (Size) as log transformation of opening market value of equity; market-to-book ratio $(M T B)$ as market value over book value of equity at the beginning of the year; capital structure (Leverage ${ }^{8}$ ) as debt-to-asset ratio. Finally, IndustryDummy and YearDummy variables represent dummies for each industry and each year.

The objective of this research question is to predict whether the CEO gender affects earnings management of a firm. However, if a firm's selection on its CEO is affected by firm characteristics or other unobservable characteristics, estimates from the OLS regression may be biased (Chaney et al. 2004). The two-stage-least-square procedure (2SLS hereinafter) from Heckman (1979), which controls for self-selection bias, may be more appropriate in such setting than the OLS method. Thus, we use the following 2SLS model to address the above issue.

${ }^{5}$ ROA is calculated as income before extraordinary items deflated by beginning total assets.

${ }^{6}$ All variables in Equations (4)-(6) are winsorized at the top and bottom 1 percent of their respective distributions.

${ }^{7}$ All continuous control variables in Equations 1,6, and 7 are winsorized at the top and bottom 1 percent to mitigate the effects of outliers.

${ }^{8}$ We include variable Leverage instead of an indicator variable for having debt as in Roychowdhury (2006). 
In the first stage, we estimate the following probit regression model (Equation 6). The dependent variable, the dummy variable Gender, is regressed on a set of control variables that are likely to affect a firm's choice on the CEO. The inverse Mills ratios are computed in the first stage.

Stage 1: the probit regression model

$$
\begin{aligned}
& \text { Gender }_{i t}=\alpha_{0}+\alpha_{1} \text { Size }_{i t-1}+\alpha_{2} \text { MTB }_{i t-1}+\alpha_{3} \text { Leverage }_{i t-1}+\alpha_{4} \text { NI }_{i t} \\
& +\alpha_{5} \log \text { Tenure } \\
& \text { it }
\end{aligned}
$$

where CEO gender (Gender) is defined as an indicator variable, set equal to one for a female CEO and zero for a male CEO. Among control variables, Size, BTM, Leverage, NI, IndustryDummy, and YearDummy are defined as Equation (1); $\log$ Tenure, $\log$ Age, and Comp are CEO tenure (as log transformation of CEO tenure), CEO age (as $\log$ transformation of CEO age), and CEO compensation (as total compensation including options exercised earned by the $\mathrm{CEO}$ during the fiscal year deflated by opening total asset).

In the second stage, we run the OLS regression in Equation (7) over each subsample divided by CEO gender. Equation (7) is the same OLS regression as Equation (1) except that Equation (7) includes the inverse Mills ratios calculated from the first stage.

Stage 2: the 2nd stage regression model

$$
\begin{aligned}
& E M_{i t}=\beta_{0}+\beta_{1} \text { Size }_{i t-1}+\beta_{2} M T B_{i t-1}+\beta_{3} \text { Leverage }_{i t-1}+\beta_{4} N I_{i t} \\
& +\beta_{5} \text { Suspect }_{i t}+\beta_{6} \text { IMR }_{i t}+\gamma_{j} \bullet \text { IndustryDummy } \\
& +\gamma_{t} \bullet \text { YearDummy }+\varepsilon_{i t}
\end{aligned}
$$

All variables other than $I M R$ are as defined in Equation (1). The inverse Mills ratio (IMR) calculated in the first stage regression is included to address the potential self-selection bias in Equation (7).

\section{Model Predictions}

When the CEO gender of a firm is male, the direction of coefficient estimate for test variable is predicted based on findings in prior studies (Roychowdhury 2006, Burgstahler and Dichev 1997, etc.). Thus, a positive (negative) and significant coefficient estimate on the test variable Suspect in Equation (1) - when the dependent variable is the performance-matched discretionary accruals $(P M D A)$ or abnormal production costs (Ab_Prod) - is consistent with the prediction that suspect firms report small positive earnings or small earnings increases through aggressive discretionary accruals or overproduction (Hypotheses 1, 2B). Similarly, a negative and significant coefficient estimate on the test variable Suspect-when the dependent variable is abnormal cash flow from operations $\left(A b_{-} C F O\right)$ or abnormal discretionary expenses (Ab_Disexp) - implies that suspect firms are more likely to engage in sales manipulation or cut discretionary expenses to boost earnings (Hypotheses 2A, 2C). On the other hand, we expect to observe an insignificant coefficient estimate on the test variable Suspect in Equation (1) for a firm with female CEO.

To compare the results estimating from the OLS with those from the 2SLS, we run Equation (6) in the 1st stage to predict the gender of a CEO from a set of control variables and then estimate test variable Suspect using Equation (7) in the 2nd stage. The predictions based on the 2SLS are anticipated to be similar to those from the OLS.

\section{MAIN RESULT}

\subsection{Descriptive Statistics}

Panel A of Table 2 presents the descriptive statistics of model variables in Equations (1) and (6) for the 14,385 firmyear observations. The mean and median values of Gender are 0.0256 (2.56\% of total sample for female CEO in Panel $\mathrm{B}$ of Table 1) and 0 , showing that the vast majority of sample firms appoint male CEOs. In general, sample firms have 
larger market value than book value (mean $M T B=3.0906)$, less debts than assets (mean Leverage $=0.1997)$ and positive net income (mean $N I=0.0487$ ). The average tenure and age of CEO are 5.85 years and 55.02 years old when the means of $\log$ Tenure and $\log$ Age are back-transformed to their original scale. The mean and median values of each earnings management measure (EM measures) are 0 or nearly 0 . While the performance-matched discretionary accruals $(P M D A)$ have both negative mean values $(-0.0013)$, all three RM measures $\left(A b_{-} C F O, A b_{-}\right.$Prod, and $A b_{-}$Disexp ) have mean value of 0 because they are residuals from each regression model. Regarding median, only the abnormal production costs have positive values $(0.0079)$ and other measures have negative median values $(P M D A=$ $\left.-0.0008 ; A b \_C F O=-0.0023 ; A b \_D i s e x p=-0.0119\right)$. Finally, only a few observations belong to suspect firm years (mean Suspect $=0.0781$ or $7.81 \%$ of total sample).

Table 2. Descriptive Statistics.

\begin{tabular}{l|c|c|c|c|c|c|c|c}
\hline Panel A. Full Sample $(1992-2013 ;$ & $\mathbf{N}=14,385$ observations $)$ & & & & & Max & N \\
\hline \multicolumn{1}{c}{ Variable } & Mean & Std Dev & Min & $\mathbf{1 Q}$ & Median & $\mathbf{3 Q}$ & \multicolumn{1}{c}{ Man } \\
\hline Gender & 0.0256 & 0.1579 & 0.0000 & 0.0000 & 0.0000 & 0.0000 & 1.0000 & 14,385 \\
\hline Size & 7.2878 & 1.6393 & 3.3769 & 6.1881 & 7.1556 & 8.3311 & 11.5499 & 14,385 \\
\hline MTB & 3.0906 & 3.4485 & -8.0294 & 1.4800 & 2.3095 & 3.7026 & 21.2003 & 14,385 \\
\hline leverage & 0.1997 & 0.1708 & 0.0000 & 0.0361 & 0.1871 & 0.3081 & 0.7582 & 14,385 \\
\hline NI & 0.0487 & 0.1106 & -0.4277 & 0.0155 & 0.0584 & 0.1025 & 0.3262 & 14,385 \\
\hline $\log$ Tenure & 1.7664 & 0.8603 & 0.0000 & 1.0986 & 1.7918 & 2.3979 & 3.5835 & 14,385 \\
\hline $\log$ Age & 4.0077 & 0.1297 & 3.6636 & 3.9318 & 4.0073 & 4.0943 & 4.3175 & 14,385 \\
\hline Comp & 3.8628 & 5.9677 & 0.0648 & 0.8404 & 1.8546 & 4.1744 & 38.8959 & 14,385 \\
\hline PMDA & -0.0013 & 0.0841 & -0.4629 & -0.0456 & -0.0008 & 0.0444 & 0.6310 & 14,385 \\
\hline Ab_CFO & 0.0000 & 0.0796 & -0.4173 & -0.0451 & -0.0023 & 0.0432 & 0.3554 & 14,385 \\
\hline Ab_Prod & 0.0000 & 0.1683 & -1.8341 & -0.0854 & 0.0079 & 0.0936 & 1.2254 & 14,385 \\
\hline Ab_Disexp & 0.0000 & 0.1395 & -0.5945 & -0.0795 & -0.0119 & 0.0635 & 0.8356 & 14,385 \\
\hline Suspect & 0.0781 & 0.2683 & 0.0000 & 0.0000 & 0.0000 & 0.0000 & 1.0000 & 14,385 \\
\hline
\end{tabular}

Panel B. Female CEOs vs. Male CEOs

\begin{tabular}{|c|c|c|c|c|c|c|}
\hline \multirow[b]{2}{*}{ Variable } & \multicolumn{2}{|c|}{ Female CEOs } & \multicolumn{2}{|c|}{ Male CEOs } & \multicolumn{2}{|c|}{ Difference } \\
\hline & Mean & Median & Mean & Median & Mean & Median \\
\hline Size & 7.1020 & 6.8402 & 7.2927 & 7.1624 & $-0.1907^{*}$ & $-0.3222^{* * *}$ \\
\hline$M T B$ & 2.9166 & 2.0294 & 3.0951 & 2.3162 & -0.1785 & $-0.2868^{* * *}$ \\
\hline leverage & 0.1784 & 0.1415 & 0.2003 & 0.1877 & $-0.0219^{* *}$ & $-0.0462^{* * *}$ \\
\hline$N I$ & 0.0355 & 0.0489 & 0.0491 & 0.0587 & $-0.0136^{* *}$ & $-0.0098^{* * *}$ \\
\hline logTenure & 1.5299 & 1.6094 & 1.7726 & 1.7918 & $-0.2428^{* * *}$ & $-0.1823^{* *}$ \\
\hline $\log A g e$ & 3.9649 & 3.9703 & 4.0089 & 4.0254 & $-0.0440^{* * *}$ & $-0.0551^{* * *}$ \\
\hline Comp & 4.4296 & 1.9060 & 3.8479 & 1.8506 & $0.5817^{*}$ & 0.0555 \\
\hline$P M D A$ & -0.0029 & -0.0026 & -0.0013 & -0.0007 & -0.0016 & -0.0019 \\
\hline$A b \_C F O$ & -0.0089 & -0.0084 & 0.0002 & -0.0022 & $-0.0091^{* *}$ & $-0.0062^{* *}$ \\
\hline$A b \_$Prod & -0.0001 & 0.0218 & 0.0000 & 0.0076 & -0.0001 & 0.0142 \\
\hline$A b \_$Disexp & 0.0180 & -0.0098 & -0.0005 & -0.0120 & $0.0185^{* *}$ & 0.0021 \\
\hline Suspect & 0.0842 & 0.0000 & 0.0779 & 0.0000 & 0.0063 & 0.0000 \\
\hline $\mathrm{N}$ & \multicolumn{2}{|c|}{368} & \multicolumn{2}{|c|}{14,017} & & \\
\hline
\end{tabular}

Note: In Panel B, mean comparisons and median comparisons are based on $t$-tests and Wilcoxon tests, respectively. ${ }^{* * *}$, **, and $*$ denote significance at the 1 percent, 5 percent, and 10 percent levels, respectively.

Panel B reports the mean and median values of each variable calculated over 368 firm-years with female CEOs and 14,017 firm-years with male CEOs. Compared to firms with male CEOs, those with female CEOs have smaller mean and median values for all control variables except variable Comp. The differences in mean (median) values between female CEO firms and male CEO firms are -0.1907 (-0.3222) for Size, $-0.1785(-0.2868)$ for MTB, $-0.0219(-0.0462)$ for Leverage, $-0.0136(-0.0098)$ for $N I,-0.2428(-0.1823)$ for $\log$ Tenure, $-0.0440(-0.0551)$ for $\log$ Age, and 0.5817 $(0.0555)$ for Comp. For any of those control variables, the mean or median difference across CEO gender is significant at the 10 percent level. ${ }^{9}$ This reveals firms run by female CEOs tend to be a smaller size with lower growth opportunity

\footnotetext{
${ }^{9}$ Based on these results, all control variables are included in Equation (6) to control the potential endogenous problem.
} 
and lower performance, but have a lower financial risk in terms of debt to asset ratio. Also, female CEOs are more likely to be younger with a shorter tenure than male CEOs while the annual compensation seems to be higher for female CEOs. Among EM measures, female CEO firms have lower mean and median values of $A b \_C F O$ than male CEO firms whereas mean values of $A b_{-}$Disexp are higher for female CEO firms, and only these differences are significant at the 5 percent level. From the mean and median differences of EM measures, earnings management level difference by CEO gender seems to be insignificant or mixed. On average, firms run by female CEO seem to be more likely to engage in sales manipulation to inflate reported earnings but maintain higher discretionary expenditure level to lower earnings, compared to those run by male CEO. Finally, consistent with the observation in Panel B of Table 1, the test variable Suspect is not statistically different between female and male CEO in terms of mean and median values.

Table 3 presents the correlations among four EM measures and independent variables (other than Industry and Year dummies) of Equation (1). The pair-wise Pearson (Spearman rank) correlations appear above (below) the diagonal. The four EM measures are highly correlated with each other at the 1 percent level. The Pearson correlation coefficients between PMDA and $A b_{-} C F O, P M D A$ and $A b_{-}$Prod, PMDA and $A b_{-}$Disexp, Ab_CFO and Ab_Prod, Ab_CFO and $A b \_$Disexp, Ab_Prod and $A b \_$Disexp are $-0.3 \overline{6} 75,0.1192,-0.0776,-0.4742,0.0 \overline{8} 00$, and -0.7354 , respectively. All EM measures are significantly correlated with the test variable Suspect at the 1 percent level as the hypothesized direction of earnings management, as documented in the previous studies. The Pearson correlation coefficients between Suspect and PMDA, Ab_CFO,Ab_Prod, and Ab_Disexp are 0.0159, -0.0240, 0.0344, and -0.0350, respectively, suggesting that suspect firms tend to report significantly larger discretionary accruals and productions costs, however, unusually low cash flow from operations and discretionary expenses. These patterns extend to the Spearman rank correlations. Untabulated results indicate that the largest variance inflation factor and the largest condition index are 1.3549 and 1.8452 , respectively. Thus, multicollinearity is remote so it is not a major concern.

Table 3. Pearson and Spearman Correlations between variables (1992-2013; $\mathrm{N}=14,385$ observations)

\begin{tabular}{l|c|c|c|c|c|c|c|c|c}
\hline & PMD & AbCFO & AbProd & AbDisexp & Size & MTB & Leverage & NI & Suspect \\
\hline \multirow{2}{*}{ PMDA } & 1.0000 & -0.3675 & 0.1192 & -0.0776 & -0.0773 & -0.0720 & 0.0011 & 0.0455 & 0.0159 \\
& & $<.0001$ & $<.0001$ & $<.0001$ & $<.0001$ & $<.0001$ & 0.8961 & $<.0001$ & 0.0563 \\
\hline \multirow{2}{*}{ AbCFO } & -0.3569 & 1.0000 & -0.4742 & 0.0800 & 0.2024 & 0.2123 & -0.1563 & 0.5020 & -0.0240 \\
& $<.0001$ & & $<.0001$ & $<.0001$ & $<.0001$ & $<.0001$ & $<.0001$ & $<.0001$ & 0.0041 \\
\hline \multirow{2}{*}{ AbProd } & 0.1269 & -0.4808 & 1.0000 & -0.7354 & -0.1587 & -0.2367 & 0.1178 & -0.2960 & 0.0344 \\
& $<.0001$ & $<.0001$ & & $<.0001$ & $<.0001$ & $<.0001$ & $<.0001$ & $<.0001$ & $<.0001$ \\
\hline \multirow{2}{*}{ AbDisexp } & -0.0900 & 0.1175 & -0.7342 & 1.0000 & 0.0919 & 0.1970 & -0.0960 & 0.0528 & -0.0350 \\
& $<.0001$ & $<.0001$ & $<.0001$ & & $<.0001$ & $<.0001$ & $<.0001$ & $<.0001$ & $<.0001$ \\
\hline \multirow{2}{*}{ Size } & -0.0687 & 0.1991 & -0.1683 & 0.0930 & 1.0000 & 0.3391 & 0.0250 & 0.3091 & 0.0237 \\
& $<.0001$ & $<.0001$ & $<.0001$ & $<.0001$ & & $<.0001$ & 0.0027 & $<.0001$ & 0.0044 \\
\hline \multirow{2}{*}{ MTB } & -0.0485 & 0.2992 & -0.3076 & 0.2304 & 0.4851 & 1.0000 & -0.0606 & 0.2335 & -0.0152 \\
& $<.0001$ & $<.0001$ & $<.0001$ & $<.0001$ & $<.0001$ & & $<.0001$ & $<.0001$ & 0.0689 \\
\hline \multirow{2}{*}{ Leverage } & 0.0026 & -0.1731 & 0.1386 & -0.1088 & 0.0876 & -0.1126 & 1.0000 & -0.1378 & 0.0346 \\
& 0.7512 & $<.0001$ & $<.0001$ & $<.0001$ & $<.0001$ & $<.0001$ & & $<.0001$ & $<.0001$ \\
\hline \multirow{2}{*}{ NI } & 0.0210 & 0.5101 & -0.3314 & 0.1189 & 0.3373 & 0.4990 & -0.2027 & 1.0000 & 0.0310 \\
& 0.0119 & $<.0001$ & $<.0001$ & $<.0001$ & $<.0001$ & $<.0001$ & $<.0001$ & & 0.0002 \\
\hline \multirow{2}{*}{ Suspect } & 0.0171 & -0.0223 & 0.0337 & -0.0339 & 0.0236 & -0.0134 & 0.0462 & 0.0002 & 1.0000 \\
& 0.0401 & 0.0076 & $<.0001$ & $<.0001$ & 0.0047 & 0.1091 & $<.0001$ & 0.9819 & \\
\hline
\end{tabular}

Note: Pearson correlation coefficients are reported above the diagonal and Spearman rank correlation coefficients are reported below the diagonal. The corresponding $p$-values appear underneath the correlation coefficients.

\subsection{OLS Analysis Based on Full Sample}

As a preliminary check before discussing earnings management on CEO gender difference, we run Equation (1) over the full sample of 14,385 observations and report the results based on each earnings management measure of $P M D A$, $A b_{-} C F O, A b_{-}$Prod and $A b_{-}$Disexp in Columns (1)-(4) of Table 4, respectively. The coefficient estimates on the test variable Suspect in all columns are consistent with findings in the previous studies on earnings management and significant at the 5 percent level. More specifically, the coefficient estimate on Suspect is positive when the dependent variable is PMDA $(0.0048 ; t$-statistics $=2.05)$ or $A b \_P r o d(0.0230 ; t$-statistics $=5.08)$, while the corresponding 
coefficient estimate is negative when the dependent variable is $A b \_C F O(-0.0097 ; t$-statistics $=-5.14)$ or $A b \_D i s e x p$ $(-0.0159 ; t$-statistics $=-3.97)$. On the whole, firms appear to increase reported earnings upward to avoid losses or earnings decline through aggressive accruals or real activities, such as sales boosting, over-production, or reduction in discretionary expenses.

Table 4. EM Regression (OLS) Results: Full sample (1992-2013).

\begin{tabular}{|c|c|c|c|c|c|c|c|c|}
\hline \multirow{2}{*}{$E M_{i t}$} & \multicolumn{2}{|c|}{ (1) PMDA } & \multicolumn{2}{|c|}{ (2) Ab_CFO } & \multicolumn{2}{|c|}{ (3) Ab Prod } & \multicolumn{2}{|c|}{ (4) Ab Disexp } \\
\hline & Coef. & $t$-stat & Coef. & $t$-stat & Coef. & $t$-stat & Coef. & $t$-stat \\
\hline Intercept & 0.0358 & $3.86^{* * *}$ & -0.0365 & $-3.76^{* * *}$ & 0.0741 & $2.82^{* * *}$ & -0.0463 & $-2.02^{* *}$ \\
\hline Size & -0.0047 & $-6.76^{* * *}$ & 0.0018 & $2.46^{* *}$ & -0.0038 & -1.53 & 0.0035 & $1.73^{*}$ \\
\hline$M T B$ & -0.0017 & $-5.07^{* * *}$ & 0.0022 & $6.32^{* * *}$ & -0.0087 & $-7.70^{* * *}$ & 0.0079 & $8.59^{* * *}$ \\
\hline Leverage & 0.0068 & 1.04 & -0.0443 & $-6.69^{* * *}$ & 0.0817 & $3.96^{* * *}$ & -0.0811 & $-4.25^{* * *}$ \\
\hline$N I$ & 0.0720 & $4.93^{* * *}$ & 0.3445 & $27.75^{* * *}$ & -0.3741 & $-13.14^{* * *}$ & -0.0211 & -0.92 \\
\hline Suspect & 0.0048 & $2.05^{* *}$ & -0.0097 & $-5.14^{* * *}$ & 0.0230 & $5.08^{* * *}$ & -0.0159 & $-3.97^{* *}$ \\
\hline YearDummy & \multicolumn{2}{|c|}{ Yes } & \multicolumn{2}{|c|}{ Yes } & \multicolumn{2}{|c|}{ Yes } & \multicolumn{2}{|c|}{ Yes } \\
\hline IndustryDummy & \multicolumn{2}{|c|}{ Yes } & \multicolumn{2}{|c|}{ Yes } & \multicolumn{2}{|c|}{ Yes } & \multicolumn{2}{|c|}{ Yes } \\
\hline Adj. $R^{2}$ & \multicolumn{2}{|c|}{$1.45 \%$} & \multicolumn{2}{|c|}{$28.13 \%$} & \multicolumn{2}{|c|}{$12.89 \%$} & \multicolumn{2}{|c|}{$4.90 \%$} \\
\hline $\mathrm{N}$ & \multicolumn{2}{|c|}{14,385} & \multicolumn{2}{|c|}{14,385} & \multicolumn{2}{|c|}{14,385} & \multicolumn{2}{|c|}{14,385} \\
\hline
\end{tabular}

Note: All $t$-values are calculated using robust standard errors to correct heteroskedasticity problem and firm clustering effect. *, ${ }^{* *}$, and ${ }^{* * *}$ indicate the significance based on $t$-value at $p$-value of less than the $10 \%$ level, $5 \%$ level, and $1 \%$ level (two-tailed), respectively.

\subsection{Main Analysis}

Table 5 presents the regression results estimated from the OLS (Equation 1) and the 2SLS (Equation 7) over the two subsamples partitioned by CEO gender based on PMDA in Panel A, $A b_{-} C F O$ in Panel B, Ab_Prod in Panel C, and $A b \_$Disexp in Panel D. In each panel, results estimating from the OLS and the 2SLS, based on the male (female) CEO sample, appear in Columns 1 and 2 (Columns 3 and 4), respectively.

When the sample is restricted to firms directed by male CEO, the coefficient estimates on Suspect, estimating both the OLS and the 2SLS, are significant at the 5 percent level in the same directions as findings based on the full sample from Table 5. The coefficient estimates on Suspect estimating from Equation (1) over the male CEO sample are 0.0047 $(t$-statistics $=2.00),-0.0097(t$-statistics $=-5.10), 0.0224(t$-statistics $=4.86)$ and $-0.0152(t$-statistics $=-3.73)$, based on dependent variable PMDA, Ab_CFO, Ab_Prod and Ab_Disexp (see Column 1 of each panel), respectively. The results do not change when the $2 \overline{S L S}$ approach is used. The corresponding coefficient estimates from the 2 SLS are $0.0047(t$-statistics $=2.00),-0.0097(t$-statistics $=-5.08), 0.0221(t$-statistics $=4.81)$, and $-0.0149(t$-statistics $=-$ 3.67), respectively, all significant at the 5 percent level (see Column 2 in Panels A-B). In contrast, when the CEO gender is female, the coefficient estimate on Suspect is insignificant, regardless of which earnings management measure is used (see Column 3). These results remain even if the 2SLS approach is used. For the female CEO sample, the coefficient estimate on Suspect, estimated from the 2SLS, is consistently insignificant across each earnings management measure based analyses. 
Table 5. EM Regression Results: Male CEO vs. Female CEO Full sample (1992-2013)

\begin{tabular}{|c|c|c|c|c|c|c|c|c|}
\hline \multicolumn{9}{|c|}{ Panel A. EM (dependent variable $)=P M D A$ and $A b \_O C F$} \\
\hline & \multicolumn{4}{|c|}{$P M D A$} & \multicolumn{4}{|c|}{$A b \_O C F$} \\
\hline & \multicolumn{2}{|c|}{ Male CEO } & \multicolumn{2}{|c|}{ Female CEO } & \multicolumn{2}{|c|}{ Male CEO } & \multicolumn{2}{|c|}{ Female CEO } \\
\hline & Coef. & Coef. & Coef. & $t$-stat & Coef. & $t$-stat & Coef. & $t$-stat \\
\hline Intercept & 0.0232 & 1.55 & -0.0305 & -0.28 & -0.0285 & $-1.82^{*}$ & -0.1157 & -1.34 \\
\hline Size & -0.0048 & $-6.76^{* * *}$ & -0.0093 & $-2.46^{* *}$ & 0.0020 & $2.62^{* * *}$ & -0.0009 & -0.28 \\
\hline$M T B$ & -0.0017 & $-5.01^{* * *}$ & -0.0028 & -1.41 & 0.0022 & $6.36^{* * *}$ & 0.0014 & 1.54 \\
\hline Leverage & 0.0039 & 0.58 & 0.0941 & $2.76^{* * *}$ & -0.0424 & $-6.18^{* * *}$ & -0.0955 & $-3.23^{* * *}$ \\
\hline$R O A$ & 0.0625 & $3.94^{* * *}$ & 0.2265 & $3.44^{* * *}$ & 0.3491 & $25.50^{* * *}$ & 0.2535 & $4.74^{* * *}$ \\
\hline Suspect & 0.0047 & $2.00^{* *}$ & 0.0093 & 1.00 & -0.0097 & $-5.08^{* * *}$ & -0.0029 & -0.28 \\
\hline$I M R$ & 0.0063 & 1.12 & 0.0318 & 0.78 & -0.0044 & -0.74 & 0.0501 & 1.36 \\
\hline YearDummy & \multicolumn{2}{|c|}{ Yes } & \multicolumn{2}{|c|}{ Yes } & \multicolumn{2}{|c|}{ Yes } & \multicolumn{2}{|c|}{ Yes } \\
\hline IndustryDummy & \multicolumn{2}{|c|}{ Yes } & \multicolumn{2}{|c|}{ Yes } & \multicolumn{2}{|c|}{ Yes } & \multicolumn{2}{|c|}{ Yes } \\
\hline Adj. $\mathrm{R}^{2}$ & \multicolumn{2}{|c|}{$1.37 \%$} & \multicolumn{2}{|c|}{$9.68 \%$} & \multicolumn{2}{|c|}{$28.25 \%$} & \multicolumn{2}{|c|}{$30.89 \%$} \\
\hline $\mathrm{N}$ & \multicolumn{2}{|c|}{13,912} & \multicolumn{2}{|c|}{367} & \multicolumn{2}{|c|}{13.912} & \multicolumn{2}{|c|}{367} \\
\hline
\end{tabular}

Panel B. EM (dependent variable) $=A b_{\_}$Prod and $A b_{-}$Disexp

\begin{tabular}{|c|c|c|c|c|c|c|c|c|}
\hline & \multicolumn{4}{|c|}{ Ab_Prod } & \multicolumn{4}{|c|}{ Ab_Disexp } \\
\hline & \multicolumn{2}{|c|}{ Male CEO } & \multicolumn{2}{|c|}{ Female CEO } & \multicolumn{2}{|c|}{ Male CEO } & \multicolumn{2}{|c|}{ Female CEO } \\
\hline & Coef. & $t$-stat & Coef. & $t$-stat & Coef. & $t$-stat & Coef. & $t$-stat \\
\hline Intercept & 0.0128 & 0.28 & 0.7064 & $2.01^{* *}$ & 0.0011 & 0.03 & -0.4586 & -1.30 \\
\hline Size & -0.0037 & -1.47 & -0.0075 & -0.60 & 0.0034 & $1.67^{*}$ & 0.0086 & 0.69 \\
\hline$M T B$ & -0.0090 & $-8.11^{* * *}$ & -0.0018 & -0.29 & 0.0082 & $8.87^{* * *}$ & 0.0018 & 0.32 \\
\hline Leverage & 0.0818 & $3.87^{* * *}$ & 0.0505 & 0.48 & -0.0825 & $-4.23^{* * *}$ & -0.0629 & -0.68 \\
\hline$R O A$ & -0.3965 & $-11.92^{* * *}$ & -0.2563 & -1.57 & -0.0053 & -0.20 & 0.0238 & 0.14 \\
\hline Suspect & 0.0221 & $4.81^{* * *}$ & 0.0051 & 0.18 & -0.0149 & $-3.67^{* * *}$ & -0.0092 & -0.34 \\
\hline$I M R$ & 0.0291 & 1.64 & -0.2865 & $-1.90^{*}$ & -0.0225 & -1.38 & 0.1889 & 1.25 \\
\hline YearDummy & \multicolumn{2}{|c|}{ Yes } & \multicolumn{2}{|c|}{ Yes } & \multicolumn{2}{|c|}{ Yes } & \multicolumn{2}{|c|}{ Yes } \\
\hline IndustryDummy & \multicolumn{2}{|c|}{ Yes } & \multicolumn{2}{|c|}{ Yes } & \multicolumn{2}{|c|}{ Yes } & \multicolumn{2}{|c|}{ Yes } \\
\hline Adj. $\mathrm{R}^{2}$ & \multicolumn{2}{|c|}{$13.18 \%$} & \multirow{2}{*}{\multicolumn{2}{|c|}{$13.50 \%$}} & \multirow{2}{*}{\multicolumn{2}{|c|}{$5.20 \%$}} & \multicolumn{2}{|c|}{$16.57 \%$} \\
\hline $\mathrm{N}$ & \multicolumn{2}{|c|}{13,912} & & & & & \multicolumn{2}{|c|}{367} \\
\hline
\end{tabular}

Taken together, these results indicate that firms in general tend to intensively use earnings management to achieve profit or earnings increases, and this seems to be mainly driven by firms with male CEOs. By comparison, female CEOs do not seem to be engaged in earnings management even when there is a strong incentive to do so. These results lend support to the predictions resulting from all the hypotheses. In addition, among male group columns, the absolute coefficient value size of test variables in case of earnings management using real activities are bigger than that using accruals.

\section{CONCLUSION}

This study examines the effect of gender on earnings management of firms over a 14-year (1992-2013) period. We hypothesize that male CEOs are likely to use aggressive discretionary accruals and real actions in order to report small positive earnings or small earnings increases whereas female CEOs are not likely to engage in aggressive earnings management. Results from both the OLS regression and Heckman's two-stage model indicate that firms with male CEOs tend to report significantly large discretionary accruals and take real actions to achieve profit or earnings increases. In contrast, we do not find evidence of aggressive earnings management by firms with female CEOs.

While we have focused on the CEO gender, there are other CEO characteristics that may affect earnings management of a firm, such as the CEO age, CEO tenure, or CEO succession path. For future research, to provide a comprehensive view we plan to examine the effects of other CEO characteristics on a firm's earnings management. This line of 
research may shed light on the findings about the CEO characteristics and earnings management in the current accounting literature.

\section{AUTHOR BIOGRAPHIES}

Kyung Na is an assistant professor in the Accounting and Taxation Department, School of Business, Keimyung University. She obtained her Ph. D from the University of Alberta, Edmonton, Canada. She also acquired her MBA from the Cambridge University in the UK and MSc in Finance from the Reading University in the UK. She is a charter holder (CFA) and has strong work experience in financial industry (Banker Trust Company, Credit Agricole Indosuez, Schroders Korea Limited, and Woori CA Asset Management Company).

Jooyeon Hong is a Doctoral student in the Accounting Department, School of Business, Sungkyunkwan University. She is a CPA in Korea and USA. She had worked for Deloitte member firm in Korea. Her research areas include audit quality, earnings management, and accounting standards. (Corresponding author) E-mail: jooyhong@skku.edu

\section{REFERENCES}

Adams, R. B., \& Funk, P. (2012). Beyond the glass ceiling: does gender matter? Management science, 58(2), 219-235.

Barua, A., Davidson, L. F., Rama, D. V., \& Thiruvadi, S. (2010). CFO gender and accruals quality. Accounting Horizons, 24(1), 25-39.

Betz, M., O'Connell, L., \& Shepard, J. M. (1989). Gender differences in proclivity for unethical behavior. journal of Business Ethics, 8(5), 321-324.

Burgstahler, D., \& Dichev, I. (1997). Earnings management to avoid earnings decreases and losses. Journal of accounting and economics, 24(1), 99-126.

Chaney, P. K., Jeter, D. C., \& Shivakumar, L. (2004). Self-selection of auditors and audit pricing in private firms. The Accounting Review, 79(1), 51-72.

Dechow, P. M., Sloan, R. G., \& Sweeney, A. P. (1995). Detecting earnings management. Accounting review, 193-225.

Degeorge, F., Patel, J., \& Zeckhauser, R. (1999). Earnings management to exceed thresholds*. The Journal of Business, 72(1), 133.

Durtschi, C., \& Easton, P. (2005). Earnings management? The shapes of the frequency distributions of earnings metrics are not evidence ipso facto. Journal of Accounting Research, 43(4), 557-592.

El Mahdy, D. F. (2015, September). Female CFOs and Real Earnings Management. In 2015 American Accounting Association Annual Meeting.

Graham, J. R., Harvey, C. R., \& Rajgopal, S. (2005). The economic implications of corporate financial reporting. Journal of accounting and economics, 40(1), 3-73.

Gunny, K. A. (2010). The relation between earnings management using real activities manipulation and future performance: Evidence from meeting earnings benchmarks. Contemporary Accounting Research, 27(3), 855-888.

Heckman, J. J. (1979). Sample selection bias as a specification error. Econometrica 47:153-162.

Hribar, P., \& Collins, D. W. (2002). Errors in estimating accruals: Implications for empirical research. Journal of Accounting research, 40(1), 105-134.

Huang, J., \& Kisgen, D. J. (2013). Gender and corporate finance: Are male executives overconfident relative to female executives? Journal of Financial Economics, 108(3), 822-839.

Jones, J. J. (1991). Earnings management during import relief investigations. Journal of accounting research, 193-228.

Khan, W. A., \& Vieito, J. P. (2013). CEO gender and firm performance. Journal of Economics and Business, 67, 55-66.

Krishnan, G. V., \& Parsons, L. M. (2008). Getting to the bottom line: An exploration of gender and earnings quality. Journal of Business Ethics, 78(1-2), 65-76.

Kothari, S. P., Leone, A. J., \& Wasley, C. E. (2005). Performance matched discretionary accrual measures. Journal of accounting and economics, 39(1), 163-197.

Lee, P. M., \& James, E. H. (2007). She'-e-os: gender effects and investor reactions to the announcements of top executive appointments. Strategic Management Journal, 28(3), 227-241.

Liu, Y., Wei, Z., \& Xie, F. (2014). Do women directors improve firm performance in China? Journal of Corporate Finance, 28, 169-184.

Niessen, A., \& Ruenzi, S. (2006). Sex matters: Gender and mutual funds. manuscript, University of Cologne.

Peni, E., \& Vähämaa, S. (2010). Female executives and earnings management. Managerial Finance, 36(7), 629-645.

Petersen, M. A. (2009). Estimating standard errors in finance panel data sets: Comparing approaches. Review of financial studies, 22(1), 435-480.

Roychowdhury, S. (2006). Earnings management through real activities manipulation. Journal of accounting and economics, 42(3), $335-370$. 
Sun, J., \& Liu, G. (2014). Audit committees' oversight of bank risk-taking. Journal of Banking \& Finance, 40, 376-387.

Shawver, T., Bancroft, P., \& Sennetti, J. (2005). Can the'Clan Effect'Reduce the Gender Sensitivity to Fraud? The Case of the IPO Environment. Journal of Forensic Accounting, 7(1): 105-208.

Vinkenburg, C. J., Van Engen, M. L., Eagly, A. H., \& Johannesen-Schmidt, M. C. (2011). An exploration of stereotypical beliefs about leadership styles: Is transformational leadership a route to women's promotion? The Leadership Quarterly, 22(1), $10-21$.

Zang, A. Y. (2011). Evidence on the trade-off between real activities manipulation and accrual-based earnings management. The Accounting Review, 87(2), 675-703. 